Revista Labor

Programa de Pós-graduação em Educação, Universidade Federal do Ceará

Fortaleza-CE-Brasil

\title{
Apresentação Geral
}

É com imenso prazer que celebramos a parceria com a Associação Brasileira de Prevenção da Evasão na Educação Básica, Profissional e Superior (ABAPEVE), ao espero seja longeva e próspera. Agradecemos o esforço, a dedicação e o compromisso com a qual nestes últimos meses dedicaram-se a organizar o Dossiê: Evasão escolar em tempos de adversidades: saberes, políticas e práticas, que ora chega aos leitores da Revista Labor.

Tem sido dias difíceis para nosso país nestes últimos anos, mais difíceis ainda para os profissionais da educação, atacados continuamente por um governo que despreza a ciência e o conhecimento de forma geral, que promove uma cultura de ódio aos docentes e à todos os profissionais da educação.

Isso se reflete nas dificuldades que as escolas e, sobretudo, nossas crianças e adolescentes têm sofrido cotidianamente para alcançar e permanecer em seus estudos. Agravou-se enormemente com a Pandemia, refletindo no crescimento sistemático da evasão escolar; ao mesmo tempo, graças aos esforços dos profissionais da educação - em muitas situações tendo o Ministério da Educação e o Governo Federal como opositores - surgem iniciativas, programas, ações, práticas e políticas que visam combater o abandono escolar.

Este dossiê, que será dividido em dois volumes, graças à grande quantidade de artigos recebidos, traz uma coletânea de estudos que apresentam os esforços para evitar que os estudantes abandonem os bancos escolares, bem como apontam os vazios e equívocos provocados por este (des)governo.

Somam-se ao dossiê os artigos de fluxo contínuo, fazendo com que em 2021 alcancemos mais de 50 artigos publicados, sendo que ainda 20 deverão entrar em um segundo volume do número 26. Axs leitorxs, estudantes, professores, pesquisadores, interessados em geral nas temáticas aqui apresentadas esperamos que possam apropriar-se das leituras utilizando-as em seus estudos e compartilhando-as com seus grupos de pesquisas e salas de aula, difundir 0 conhecimento científico produzir é, nesse momento, o melhor caminho para superarmos essa onda destrutiva que avançou em nosso país.

Cordial e carinhosamente,

Prof. Eneas de Araújo Arrais Neto - Editor da Revista Labor

Prof. Jerciano Pinheiro Feijó - Equipe Técnica Revista labor 